\title{
A novel spectrophotometric method development and validation of Tenagliptin in its Tablet dosages form
}

\author{
Patra Poulami ${ }^{1}$, Ghosh Somsubhra ${ }^{* 1}$, Roy Tathagata ${ }^{2}$, Ravi kumar B. V. V. ${ }^{3}$ \\ ${ }^{1}$ NSHM Knowledge Campus, Kolkata - Group of Institutions, 124 - B. L. Saha Road, Tollygaunge, Kolkata-700053. \\ 2 Department of Pharmacy, JIS University, 81, Nilgunj road, Kolkata- 700109 \\ 3 Principal, Roland Institute of Pharmaceutical Sciences, Berhampur - 760010, Odisha.
}

\begin{abstract}
The aim of present work was to develop a new, economical \& simple analytical method of Teneligliptin \& its validation as per International Conference on Harmonization (ICH) guideline, which is a new antidiabetic drug that is used to treat Non-Insulin Dependent Diabetis Melitus (NIDDM) patients. A sensitive and specific Ultra Violet (UV) Visible method was developed \& the analysis was carried out by using Shimazdu 1800 Spectrophotometer, $0.1(\mathrm{~N}) \mathrm{NaOH}$ was used as a solvent. The UV- Visible Spectrophotometric estimation was carried out at a $\lambda$ max of 242 $\mathrm{nm}$ using $1 \mathrm{~cm}$ thick quartz cell. Validation of the newly developed method was performed as per International Conference on Harmonization (ICH) Q2R1 guideline in the following parameters: Calibration curve, Accuracy, Precision etc. Newly developed method obeys Beer's-Lambert's law in the concentration range of $5-25 \mu \mathrm{g} / \mathrm{ml}$, whereas correlation coefficient value is less than 1 . The percent amount of drug estimated by this developed method was $100.91 \%$, which is very close to $100 \%$. The validation parameters like Accuracy, Precision, Linearity, Range, Limit of detection (LOD) \& Limit of Quantification (LOQ) were studied for the developed method and was found to be within the limits.
\end{abstract}

Keywords: Teneligliptin, Validation, Method, Spectroscopy etc.

Article Info: Received 18 June 2019; $\quad$ Review Completed 10 Aug 2019; $\quad$ Accepted 26 Aug $2019 ; \quad$ Available online 15 Sep 2019

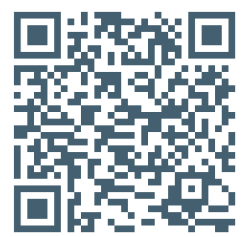

\section{Cite this article as:}

Patra P, Ghosh S, Roy T, Ravi Kumar BVV, A novel spectrophotometric method development and validation of Tenagliptin in its Tablet dosages form, Journal of Drug Delivery and Therapeutics. 2019; 9(5):95-98

http://dx.doi.org/10.22270/jddt.v9i5.3503

Ghosh Somsubhra, NSHM Knowledge Campus, Kolkata - Group of Institutions, 124 - B. L. Saha Road, Tollygaunge, Kolkata-700053.

\section{INTRODUCTION:}

Analytical chemistry ${ }^{1}$ is an important branch of Chemistry. It is employed in separating, identifying and determining the relative amounts of the components making up a sample of matter. Distillation and precipitation techniques for the separation of components of complex mixtures prior to their qualitative or quantitative determination were replaced by sophisticated Chromatographic techniques 2. Methods for separation and determination of chemical species are known collectively as instrumental methods of analysis. Most important instrumental methods like Spectroscopy, electrochemistry and Chromatography are used widely in present days ${ }^{3}$.

The absorption spectroscopy is based on the measurement of transmittance $\mathbf{T}$ or the absorbance $\mathbf{A}$ of a sample solution filled in the transparent cell having a path-length of $1 \mathrm{~cm}$. Generally absorbance is liner with the concentration $\mathbf{c}$ of the absorbing analyte, as represented by the following equation;

$$
A=-\log \mathbf{T}=\mathbf{k c l}
$$

Where, $\mathrm{k}$ is the absortivity of the analyte. The photometric methods of analysis are based on the Bouger-Lambert-Beer's law, which establishes the absorbance of a solution is directly proportional to the concentration of the analyte. electronic excitation is found due to absorption of relatively high - energy radiation. ${ }^{4-6}$.

Teneligliptin is an antidiabatic drug. It inhibits human dipeptidyl peptidase-4(DPP-4). By inhibiting it prevented the degradation of incretins GLP-1, GIP and promoted insulin release. The IUPAC name $\{(2 \mathrm{~S}, 4 \mathrm{~S})$ - 4- [4- (3- methyl1phenyl- 1Hpyrazol- 5-yl) piperazin- 1-yl] pyrrolidin- 2-yl $\}$ (1, 3-thiazolidin-3yl) methanone hemipentahydrobromide hydrate $7-8$.<smiles>Cc1cc(N2CCN([C@@H]3CN[C@H](C(=O)N4CCSC4)C3)CC2)n(-c2ccccc2)n1</smiles>

Figure 1. Shows structure of Teneligliptin 
Literature review ${ }^{9-13}$ for Tenagliptin shows that, there are very few methods based on different techniques. However, there is no method reported for the detection of Teneligliptin alone, in bulk and Pharmaceutical formulation by UV - Visible Spectrophotometry. The aim of present work was to establish a very simple, sensitive, specific, Spectrophotometric method development and its validation for the detection of Tenagliptin in bulk drug and Pharmaceutical formulation.

\section{MATERIALS AND METHODS:}

\section{Instrument:}

A Shimadzu-1800 UV-Visible double beam Spectrophotometer with $1 \mathrm{~cm}$ matched quartz cells was used for all spectral measurements. Authentic drug sample of Teneligliptine was given as a gift sample by Zydus Cadila, Ahmedabad. Tablets of Teneligliptin procured from local market.

\section{Methods:}

Solvents used for the determination of Teneligliptine in UV Spectrophotometer:

Uv - Visible Spectrophotometric method which involves the determination of Teneligliptine in Pharmaceutical formulation and has an absorption maximum at $244 \mathrm{~nm}$ in $0.1 \mathrm{~N} \mathrm{NaOH}$. It obeys beer's law in concentration range $5-25$ $\mu \mathrm{g} / \mathrm{ml}$.

\section{Solvent selection:}

In order to select suitable solvent for determination of Teneligliptine, various solvents were selected for the solubility studies and it was found that Teneligliptine was freely soluble in the following solvents: water, ethanol, methanol, 0.1N NaOH, Acetonitrile, DMSO (Di Methyl Sulfa Oxide) etc. In the present investigation 0.1 (N) $\mathrm{NaOH}$ was used for initial dilution and all the remaining dilutions also carried out by Water only.

\section{Preparation of standard stock solution:}

It was prepared by dissolving accurately weighed $50 \mathrm{mg}$ of Teneligliptine in $50 \mathrm{ml}$ of $0.1 \mathrm{~N} \mathrm{NaOH}$ in $50 \mathrm{ml}$ volumetric flask (stock solution-1, $1000 \mu \mathrm{g} / \mathrm{ml}$ ). $1 \mathrm{ml}$ of stock solution-1 was diluted to $10 \mathrm{ml}$ with Water (stock solution-2, 100 $\mu \mathrm{g} / \mathrm{ml}$ ), then $1 \mathrm{ml}$ of stock solution- 2 was diluted to $10 \mathrm{ml}$ with Water (stock solution-3, $10 \mu \mathrm{g} / \mathrm{ml}$ ). Then absorbance of resulting solution was measured against respective blank solution in the UV region of $200-400 \mathrm{~nm}$, which shows maximum absorbance at $242 \mathrm{~nm}$.

\section{Preparation of standard curve:}

Aliquots of standard solution - 2 of Teneligliptine ranging from $0.5 \mathrm{ml}-2.5 \mathrm{ml}$ were transferred into a series of $10 \mathrm{ml}$ volumetric flasks separately to prepare concentration ranges from $5 \mu \mathrm{g} / \mathrm{ml}$ to $25 \mu \mathrm{g} / \mathrm{ml}$. The volume in each flask was made up to $10 \mathrm{ml}$ with water and the absorbance were measured at $242 \mathrm{~nm}$ against solvent blank and the absorbance values. The obtained absorbance values are plotted against the concentration of Teneligliptine to get the calibration graph. The concentration of the unknown sample was determined from the calibration graph. The correlation coefficient was determined.

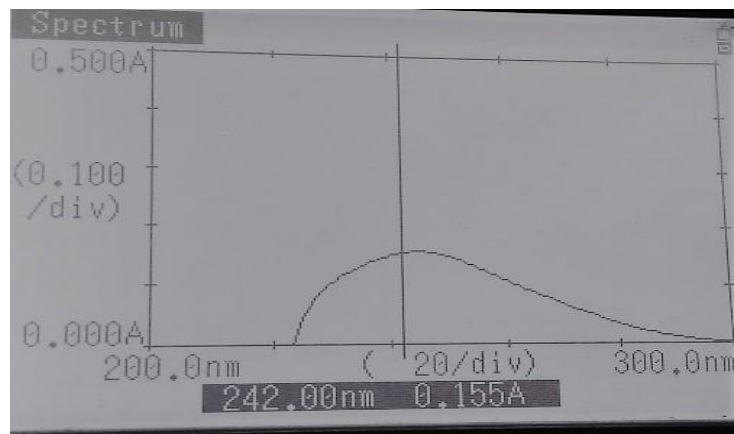

Figure 2. Shows UV Spectrum of Teneligliptin

\section{Sample preparation of Teneligliptin:}

Taken 10 tablets, powdered and weighed accurately equivalent to $50 \mathrm{mg}$ of Teneligliptin was taken to a $50 \mathrm{ml}$ cleaned and dried volumetric flask. This was then diluted with $0.1 \mathrm{~N} \mathrm{NaOH}$ solution upto $50 \mathrm{ml}$. Then taken $1 \mathrm{ml}$ of sample solution and dilute with Water, volume was made up to $10 \mathrm{ml}(100 \mu \mathrm{g} / \mathrm{ml})$. This was marked and labeled as Stock solution. Further, an amount of $1 \mathrm{ml}$ was pipetted out from the above stock solution into a $10 \mathrm{ml}$ volumetric flask and diluted up to the mark with diluent to get $10 \mu \mathrm{g} / \mathrm{ml}$.

\section{Method validation:}

Various methods for analysis of Tenagliptin in bulk and Pharmaceutical formulation were carried out. Then the developed method was validated in the following parameters as ICH Q2B guideline

\section{Accuracy:}

Accuracy is the closeness if the test results obtained by the method to the true value. To study the accuracy, 10 tablets of Teneligliptin were taken, powdered the tablets used to carry out the analysis. Recovery studies were carried out by addition of standard solution $(5,10,15 \mu \mathrm{g} / \mathrm{ml})$ to the sample at 3 different concentration levels.

\section{Precision:}

Accurately weighed amount of $50 \mathrm{mg}$ of Teneligliptin was taken to a $50 \mathrm{ml}$ cleaned and dried volumetric flask. This was then dissolved with $0.1 \mathrm{~N} \mathrm{NaOH}$ up to $50 \mathrm{ml}$. Then $1 \mathrm{ml}$ of sample solution was taken and dilute with Water, volume was made up to $10 \mathrm{ml}(100 \mu \mathrm{g} / \mathrm{ml})$. Further, an amount of $1 \mathrm{ml}$ was pipetted out from the above stock solution into a 10 $\mathrm{ml}$ volumetric flask and diluted up to the mark with diluent to get $10 \mu \mathrm{g} / \mathrm{ml}$. Then 6 replicates of $10 \mu \mathrm{g} / \mathrm{ml}$ solutions was prepared in the same manner.

\section{Linearity:}

Five point Linearity curve was generated with the appropriate volumes of the working standard solutions for UV methods.

\section{Limit of Detection:}

The Limit of detection is the lowest concentration of the analyte in a sample that can be detected but not necessarily determined in a quantitative fashion using a specific method under the required experimental conditions. Such a limit is expressed in terms of a concentration of analyte (example:$\mu \mathrm{g} / \mathrm{lit}$ ) in the sample.

LOD = 3.3 SD / S where, SD - is the Standard Deviation, ' $\mathbf{S}$ is the slope of the calibration curve for analyte. 


\section{Limit of Quantification:}

The LOQ is the lowest concentration of analyte in a sample that may be measured with an acceptable level of accuracy and precision under the above mentioned conditions of the method. LOQ value varies with the method used \& the nature of sample.

LOQ = 10 SD / S, where, SD - is the Standard Deviation, 'S' is the slope of the calibration curve for analyte.

\section{RESULTS AND DISCUSSION:}

The development of a simple, rapid, sensitive and accurate analytical method for the routine quantitative determination of samples will reduce unnecessary tedious sample reparations and the cost of materials and labour. Specific chromophore present in the structure of Tenapliptin molecule, absorb at a particular wavelength of UV region and this fact was successfully employed for their quantitative determinations using the UV - Visible Spectrophotometric method. The absorption maxima $\left(\lambda_{\max }\right)$ of the drug was determined by taking scans of the drug sample solutions in the entire UV region. It was found to be that only one peak was observed in this method at the wavelength of $242 \mathrm{~nm}$ ( $\left.\lambda_{\max }\right)$.

Accuracy:

Table 1: Accuracy Data of Teneligliptin

\begin{tabular}{|l|l|l|l|l|l|l|}
\hline \multirow{2}{*}{ \%CONC } & Absorbance & $\begin{array}{l}\text { CONC. } \\
(\boldsymbol{\mu g} / \mathbf{m l})\end{array}$ & \%Purity & \%Recovery & \%Mean \\
\cline { 2 - 7 } & Standard solution & Sample solution & 5 & 106.7 & & \\
\hline $50 \%$ & 0.093 & 0.099 & 5 & 107.8 & 106.63 & \\
\hline $50 \%$ & 0.090 & 0.097 & 5 & 105.4 & & \\
\hline $50 \%$ & 0.091 & 0.096 & 10 & 98.2 & & 101.91 \\
\hline $100 \%$ & 0.290 & 0.265 & 10 & 98.1 & 98.3 & \\
\hline $100 \%$ & 0.270 & 0.283 & 10 & 98.6 & & \\
\hline $100 \%$ & 0.287 & 0.330 & 15 & 101.2 & & \\
\hline $150 \%$ & 0.326 & 0.328 & 15 & 98.8 & 100.8 & \\
\hline $150 \%$ & 0.332 & 0.337 & 15 & 102.4 & & \\
\hline $150 \%$ & 0.329 & &
\end{tabular}

\section{Acceptance Criteria:}

The \% Recovery should be between 98.0 to $102.0 \%$ in each level.

The results obtained for recovery are within the limits.

So, it is observed from the above table that, accuracy of the newly developed method is $101.91 \%$, which is mentioned in table 1 . Hence the method is accurate.

\section{Precision:}

Table 2: Precision Data of Teneligliptin

\begin{tabular}{|l|l|}
\hline Concentration $(\boldsymbol{\mu g} / \mathbf{m l})$ & Absorbance \\
\hline 10 & 0.240 \\
\hline 10 & 0.245 \\
\hline 10 & 0.245 \\
\hline 10 & 0.247 \\
\hline 10 & 0.248 \\
\hline 10 & 0.246 \\
\hline Mean & 0.245 \\
\hline S.D & 0.00279 \\
\hline \% RSD & 1.13 \\
\hline
\end{tabular}

\section{Acceptance criteria:}

$\%$ RSD of different analytes should not be more than 2 . The $\%$ RSD value of the newly developed method is 1.13 , as mentioned in Table 2. Which is within the limit, hence the method is precise.

\section{Linearity \& Range:}

Table No 3: Linearity Table of Teneligliptin

\begin{tabular}{|c|c|}
\hline Concentration $(\boldsymbol{\mu g} / \mathbf{m l})$ & Absorbance \\
\hline 5 & 0.134 \\
\hline 10 & 0.240 \\
\hline 15 & 0.342 \\
\hline 20 & 0.444 \\
\hline 25 & 0.547 \\
\hline
\end{tabular}

ISSN: 2250-1177

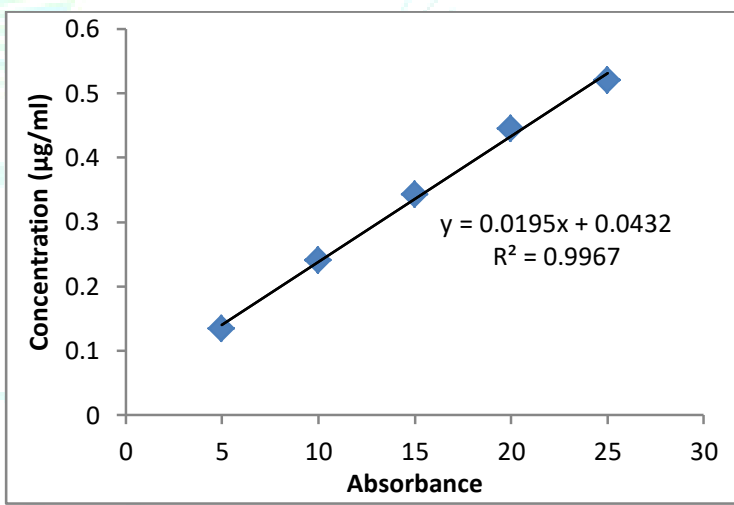

Figure 3. Linearity Graph of Teneligliptin Acceptance criteria:

Correlation coefficient $\left(\mathrm{R}^{2}\right)$ should not be less than 0.999

The correlation coefficient obtained was 0.996 in the newly developed method, as per Table 3. which is very near to acceptance limit. The linearity was established in the range of $5 \%$ to $25 \%$ for Teneligliptin, which is mentioned in Fig. 3.

\section{LOD \& LOQ:}

The LOD \& LOQ were calculated as per the formulas, mentioned above \& was reported as follows.

Table No 4: LOD \& LOQ Table

\begin{tabular}{|c|c|c|}
\hline Sample & LOD $(\boldsymbol{\mu g} / \mathbf{m l})$ & LOQ $(\boldsymbol{\mu g} / \mathbf{m l})$ \\
\hline Teneligliptin & 0.42 & 1.42 \\
\hline
\end{tabular}




\section{CONCLUSION:}

A simple, economic, accurate and precise UV - Vis Spectrophotometric method was successfully developed. The method developed was statistically validated in terms of Accuracy, Linearity, Precision, LOD, LOQ. Statistical result of all the validation parameter was within the prescribed limits. Solvent is very economic\& very easy to prepare. Hence, the UV Spectrophotometric method developed for Teneligliptin in Tablet dosages form was found to be economic, rapid, simple, sensitive, precise, and accurate.

\section{REFERENCES:}

1. Becket and Stenlake, Practical Pharmaceutical Chemistry, 24th ed. CBS publications and distributors, 2005; p157-168.

2. Sharma YR, Elementary Organic Spectroscopy, $5^{\text {th }}$ ed. S. Chand; 2013, p11-40.

3. Dewan SK, Organic Spectroscopy, $1^{\text {st }}$ ed. CBS Publishers \& Distributors; 2010, p581-613.

4. Kalsi PS, Spectroscopy of Organic Compound, $6^{\text {th }}$ ed. New Age International (P) Ltd., 2016; p11-50.

5. John R. Dyer, Application of Absorption of Spectroscopy of Organic Compounds, PHI Learning Pvt. Ltd., p. 4-21.

6. Sethi PD, HPLC quantitative analysis of Pharmaceutical formulations, CBS publications and distributors, $1^{\text {st }}$ ed, 2001 , p. 69-70.
7. Kishimoto M, Teneligliptin: a DPP-4 inhibitor for the treatment of type 2 diabetes, Diabetes Metab Syndr Obes 2013; 6: 187195.

8. Available at: https://en.wikipedia.org/wiki/Dipeptidyl_peptidase4_inhibitor, accesed on 10/08/2108.

9. Hemke AT, Rathod EA, Gupta KR, Umekar MJ, HPLC and UVSpectrophotometric Estimation of Teneligliptin from Tablet Dosage Form, Asian Journal of Pharmacetical Analysis and Medicinal Chemistry, 2016; 4 (3):148- 156.

10. Sen AK, Hinsu DN, Sen DB, Zanawar AS, Maheshwar AS Chandrakar VR, Analytical method development and validation for simultaneous estimation of Teneligliptin Hydrobromide hydrate and Metformin Hydrochloride from it's pharmaceutical dosage form by three different UV Spectrophotometric methods, Jouranal of Applied Pharmaceutical Sciencs, 2016; 6 (09): 157-165.

11. Patil MD, Bapna MD, Shah P, Khoja SS, Development and Validation of Analytical Method for Simultaneous Estimation of Metformin Hydrochloride and Teneligliptin Hydrobromide Hydrate in Pharmaceutical Dosage Form, Journal of Pharmaceutical Science and Bioscientific Research, 2017; 7(2): 200-208.

12. Neeraja T, Sridevi $P$, Vintha $K$, Raju MB, A Stability Indicating UPLC Method for Simultaneous Determination Of Teneligliptin Hydrobromide Hydrate And Metformin Hydrochloride In Bulk and Tablet Dosage Form, International Journal of Pharmaceutical Sciences and Research, 2018; 9(8): 32973306. 